\title{
Fat Wasting Is Damaging: Role of Adipose Tissue in Cancer-Associated Cachexia
}

\author{
Xiaoting Sun ${ }^{1}$, Xiaogang Feng ${ }^{2}$, Xiaojing Wu ${ }^{3}$, Yongtian $\mathrm{Lu}^{4 *}$, Kaihong $\mathrm{Chen}^{5 *}$ and \\ Ying Ye ${ }^{6 *}$
}

${ }^{1}$ Department of Medical Oncology, Shuguang Hospital, Shanghai University of Traditional Chinese Medicine, Shanghai, China, ${ }^{2}$ Institute of Physiology, University of Zurich, Zurich, Switzerland, ${ }^{3}$ Department of Cardiology, Shenzhen University General Hospital, Shenzhen, China, ${ }^{4}$ Department of ENT, Shenzhen Second People's Hospital, The First Affiliated Hospital of Shenzhen University, Shenzhen, China, ${ }^{5}$ Department of Cardiology, The Affiliated Longyan First Hospital of Fujian Medical University, Longyan, China, ${ }^{6}$ Department of Oral Implantology, School and Hospital of Stomatology, Tongji University,

Shanghai Engineering Research Center of Tooth Restoration and Regeneration, Shanghai, China

\section{OPEN ACCESS}

Edited by:

Lasse Dahl Ejby Jensen,

Linköping University, Sweden

Reviewed by:

Ana Paula Santos-Silva,

Federal University of Rio de Janeiro,

Brazil

Jun Yan,

Nanjing University, China

${ }^{*}$ Correspondence:

Yongtian Lu

luyongtian@263.net

Kaihong Chen

kaihongchen2019@hotmail.com

Ying Ye

ying.ye@tongji.edu.cn

Specialty section:

This article was submitted to

Molecular and Cellular Oncology,

a section of the journal

Frontiers in Cell and Developmental

Biology

Received: 11 November 2019

Accepted: 15 January 2020

Published: 12 February 2020

Citation:

Sun $X$, Feng $X$, Wu X, LU Y Chen $K$ and $Y e Y$ (2020) Fat Wasting Is Damaging: Role of Adipose Tissue

in Cancer-Associated Cachexia.

Front. Cell Dev. Biol. 8:33.

doi: 10.3389/fcell.2020.00033
Loss of body weight, especially loss of adipose tissue and skeletal muscle weight, characterizes cancer-associated cachexia (CAC). Clinically, therapeutic options for CAC are limited due to the complicated signaling between cancer and other organs. Recent research advances show that adipose tissues play a critical role during thermogenesis, glucose homeostasis, insulin sensitivity, and lipid metabolism. Understanding the adipocyte lipolysis, the formation of beige adipocytes, and the activation of brown adipocytes is vital for novel therapies for metabolic syndromes like CAC. The systemlevel crosstalk between adipose tissue and other organs involves adipocyte lipolysis, white adipose tissue browning, and secreted factors and metabolites. Novel CAC animal models and accumulating molecular signaling knowledge have provided mechanisms that may ultimately be translated into future therapeutic possibilities that benefit CAC patients. This mini review discusses the role of adipose tissue in CAC development, mechanism, and therapy.

Keywords: adipose tissue, browning, lipolysis, thermogenesis, cancer cachexia

\section{INTRODUCTION}

Cancer-associated cachexia (CAC) has a unique tumor-driven pattern that can lead to progressive functional impairment, treatment-related complications, poor quality of life, and mortality. It is defined by an ongoing loss of skeletal muscle mass, with or without loss of fat mass, that can be partially but not entirely reversed by conventional nutritional support (Fearon et al., 2011). The diagnosis of CAC is based on the speed of weight loss and the BMI index. Recent assessments have suggested that CAC affects $60-80 \%$ of advanced cancer patients and directly causes at least $20 \%$ of cancer death (Stewart et al., 2006). CAC patients are more susceptible to the toxic effects of anti-tumor therapies such as chemotherapy, while the increased toxicity requires drug withdrawal and dose reduction in cancer treatment, and it therefore increases morbidity and mortality. This fatal disease can be divided into three typical stages: pre-cachexia, cachexia, and refractory cachexia (Argiles et al., 2011). Patients with CAC have significant weight loss, anorexia, anemia, fatigue, 
intestinal malabsorption, nausea, profound endocrine alterations, and metabolic chaos, with severe disruption of protein, lipid, and carbohydrate metabolism (Tisdale, 2002).

It is agreed that CAC is an energy balance disorder in which the tumor competes with other organs and tissues for fuel and biosynthetic substrates (Argiles et al., 2014). The intrinsic metabolic rate defined by aerobic versus anaerobic energy metabolism is essential for CAC progression. Various energy expenditure-related pathways are suggested in the development of CAC. About 40 years ago, researchers found that futile cycles that reduce efficiency in adenosine triphosphate (ATP) usage contribute to the hypermetabolism. For example, the Cori cycle, a lactate-glucose carbon recycling system between the muscle and liver, may nourish the tumor (Holroyde and Reichard, 1981). Recently, leakiness of the respiratory electron-transport chain is found to confer high energy expenditure. Instead of ATP synthase, Uncoupling protein 1 (UCP1), which is only expressed in brown or beige adipocytes, speeds up respiration and converts electrochemical energy into heat production (Bing et al., 2000). Moreover, other mitochondria abnormities, such as atrophy of oxidative capacity (Julienne et al., 2012), may be involved in muscle weight loss.

As a multi-organ syndrome, CAC is closely associated with skeletal muscle, adipose tissue, the bone, the liver, the neural system, and the gut (Argiles et al., 2018). Among these organs, the communication between the adipose tissue and tumor is under intense investigation. Although studies have suspected the relationship between the adipose tissue and tumor for over 30 years (Brooks et al., 1981; Shellock et al., 1986), the detailed mechanisms have only recently been discovered. Adipose tissue is one of the largest organs in humans. Besides energy storage, accumulating evidence demonstrates its unveiled roles within endocrinology, energy consumption, thermogenesis, stem cell pool, neuronal differentiation, and inflammatory regulation. However, its crosstalk with the tumor is largely overlooked. In humans, white adipose tissue (WAT) is mainly composed of large spherical adipocytes, in which a unilocular lipid droplet occupies most of the cell volume. WAT possesses endocrine and paracrine functions and stores energy in the form of triglycerides. In comparison, brown adipocytes in brown adipose tissue (BAT) exhibit a substantial amount of mitochondria and scattered cytoplasmic droplets. The most distinguished signature in BAT is its high-level expression of mitochondrial UCP1, which is the key to lipid oxidation and thermogenesis. Another type of adipocyte, the "beige" adipocyte, originated from white adipocyte but expresses UCP1, shows plasticity, and can be transited from white adipose tissue by various signals (Rosen and Spiegelman, 2006). Clinically, WAT browning and BAT activation are considered as promising methods for combating obesity and metabolic syndromes. On the contrary, similar activities under local or distant stimuli in cancer make them potential causes of CAC. In this review, we focus on the role of adipose tissue dysfunction in CAC and review the molecular mechanism that underlies it. An adequate understanding of this system-level adipose tissue crosstalk will be beneficial for novel treatments for CAC.

\section{WAT Lipolysis in CAC}

The white adipocyte is the major storage space for triacylglycerol (TAG), and the balance of lipolysis/lipogenesis maintains the dynamic homeostasis in the adipocyte, as well as guides the systemic energy production in CAC. Independent of malnutrition, adipocyte lipolysis is strongly involved in CAC, inducing lipid loss (Ryden et al., 2008). Lipolytic factors or hormones, such as tumor necrotic factor $\alpha$ (TNF $\alpha)$ (Oliff et al., 1987), interleukin-6 (IL-6) (Strassmann et al., 1992), Zinc- $\alpha 2$ glycoprotein (ZAG) (Bing et al., 2004), catecholamines, and natriuretic peptides (Kalra and Tigas, 2002), explain lipolysis in cancer cachexia. Following this line, recent studies show that two key lipases (Agustsson et al., 2007; Das et al., 2011), which break down the fat, mediate CAC, and serve as potential targets for CAC treatment. Other than the canonical pathways, lipolysis can also be regulated by degradation of perilipin, a lipid droplet-associated packaging protein (Kovsan et al., 2007). However, its relationship with CAC warrants further investigation. Besides, de novo lipogenesis is reduced in tumorbearing animals (Trew and Begg, 1959). Lipogenic enzymes, such as lipoprotein lipase (LPL) and fatty acid synthase (FAS), are significantly reduced in the adipose tissue adjacent to the tumor (Notarnicola et al., 2012), validating the tumorsupporting role of WAT in CAC. Other than lipolysis per se, inflammation is a well-known driving force for WAT lipolysis. CAC is correlated with profound inflammation, which may, in turn, stimulates WAT loss, suggesting inflammatory cytokines may serve as biomarkers for CAC diagnosis. Indeed, animal models show a strong correlation between tumor presence and elevated serum inflammatory cytokines (Das et al., 2011). However, the association between serum cytokines and fat loss in patients is somewhat ambiguous (Blum et al., 2011), probably due to the transient and diverse-origin nature of serum cytokines. Though further validation is needed, lipolysisrelated CAC biomarkers in peripheral blood are particularly important for diagnosis.

Reserving excess lipids and regulating circulating fatty acid (FA) to other organs are major functions of the white adipocyte. During CAC, lipolysis activation in WAT may increase the circulating FA. Consequently, lipid overload may process a secondary effect on various organs. It is suspected that tumor benefits from the releasing FA during CAC. Indeed, in an acute fasting model, circulating FA greatly increased tumor proliferation (Sauer et al., 1986). In accordance with this, our work showed that a hypoxia-induced metabolic shift promotes tumor FA importation and $\beta$-oxidation (Iwamoto et al., 2018). In other non-adipose organs, lipotoxicity is also widely reported in liver, skeleton muscle, pancreas, and heart (van Herpen and Schrauwen-Hinderling, 2008).

\section{Browning in CAC}

In WAT, sympathetic stimulations, such as cold exposure or a $\beta 3$ agonist, strongly increase thermogenic beige adipocytes. This process is termed as "browning". Various recent studies have reported that an upregulated browning process promotes energy expenditure and CAC (Kir et al., 2014; Petruzzelli et al., 2014). 
By neutralizing the browning stimulator parathyroid hormonerelated protein (PTHrP), CAC is ameliorated and fat loss is rescued in animal models (Kir et al., 2014). Additionally, jeopardizing the tumor-derived exosome, which is a vehicle for possible browning stimulators, rescued fat loss in tumor-bearing mice (Hu et al., 2018). These findings suggested the anti-CAC effect of the browning blockade. Understanding the mechanism of beige cell differentiation and UCP1 production is crucial for combating CAC. During the last decade, the transcriptional regulation of UCP1 has been elucidated. Peroxisome proliferatoractivated receptor $\gamma(\operatorname{PPAR} \gamma)$ (Rosen et al., 2002), PPAR $\gamma$ coactivator $1 \alpha$ (PGC-1 $\alpha$ ) (Puigserver et al., 1998), PR domain containing 16 (PRDM16) (Seale et al., 2007), and other transcription factors are responsible for UCP1 production in brown and beige adipocytes. Other than that, extracellular stimulations, such as catecholamines (Nguyen et al., 2011), crotamine (Marinovic et al., 2018), prostaglandins (Vegiopoulos et al., 2010), fibroblast growth factor 21 (FGF21) (Dutchak et al., 2012), ZAG (Elattar et al., 2018), Bone morphogenetic proteins (BMPs) (Tseng et al., 2008), and alcohol-retinoic acid axis (Wang et al., 2017), have recently been reported to elevate the browning process and facilitate CAC. During the browning process, beige cells de novo originated from a smooth muscle cell-like lineage and can be converted back to the "white-like" phenotype (Rosenwald et al., 2013; Wang et al., 2013), while PRDM16 (Long et al., 2014) and BMP7 (McDonald et al., 2015) serve as strong stimulators for their differentiation. Although various mechanisms, such as autophagy, microflora, exosome, and long non-coding RNAs, have been reported to be involved in the WAT browning process, whether or not this confers CAC is not fully validated. Only a handful of studies exhibited an anticachexia effect in limited animal models. Future studies should focus on these targets from a clinical point of view.

Interestingly, white adipose depots show heterogeneity in browning efficiency. Certain depots, such as inguinal WAT, are sensitive to browning stimulation, while visceral fat depots are resistant to browning. The latter was previously identified as being "true white adipose tissue" and harmful. Considering the browning ability differences, do adipose depots contribute to CAC differently? It has been reported that visceral fat may switch its phenotype for browning under certain stimulations (Yang et al., 2017), though the switching mechanism is still not well understood. This interesting question warrants further investigation and may improve our understanding of the mechanism of browning-conferred CAC.

\section{BAT Activation in CAC}

BAT depots are highly vascularized, and the interscapular site is the main location for BAT in rodents (Rosen and Spiegelman, 2014). Except for specific markers, such as the Zinc finger in the cerebellum 1 (Zic1), brown adipocytes share overlapping gene signatures with beige adipocytes (Walden et al., 2012). Compared with beige cells, brown adipocytes have a higher basal level of UCP1 expression (Wu et al., 2012). From a developmental point of view, brown adipocytes are marked by transcription factors myogenic factor 5 (Myf5) (Seale et al., 2008) and paired box 7 (Pax7) (Lepper and Fan, 2010), similarly to myogenic precursor cells. Brown fat precursor cells that express early B cell factor 2 (EBF2) and platelet-derived growth factor receptor $\alpha$ (PDGFR $\alpha$ ) process de novo differentiation into mature brown adipocytes (Wang et al., 2014). $\beta 1$-adrenergic receptor (ADRB1) also mediates norepinephrine-induced de novo brown adipogenesis in BAT (Lee et al., 2015). Interestingly, ADRB1 expression is correlated with the lipolytic rate in CAC patients (Cao et al., 2010), suggesting that a BAT blockade may be a potential therapy for CAC. Although speculated for a long time (Shellock et al., 1986), the clinical evidence that BAT contributes to CAC is limited. This may be due to the small amount and sporadic distribution of adult BAT in humans as well as restrictions of current imaging methods to describe BAT and quantify its function.

Interestingly, loss of brown adipocytes may sequentially induce WAT browning, indicating a compensatory mechanism between mature brown and beige adipocyte (Schulz et al., 2013). It would be exciting to identify whether this mechanism exists in CAC.

\section{Adipocyte-Non-adipocyte Crosstalk in CAC}

As a multi-functional organ, adipose tissue communicates with various cell types. In the context of CAC, the adipocytemyocyte, adipocyte-cancer cell, and adipocyte-inflammatory cell crosstalk have received particular attention. Firstly, adipocytes and skeletal muscle communicate in CAC: (1) brown adipocyte share the same lineage origin with skeletal muscle and may respond to similar signals (Seale et al., 2008); (2) the fibroadipogenic precursor in the muscle may differentiate into white adipocyte in CAC (Stephens et al., 2011); (3) adipocytederived cytokines stimulate muscle atrophy (Pellegrinelli et al., 2015); and (4) myokines, such as irisin and FGF21, promote browning and fat loss (Bostrom et al., 2012; Veniant et al., 2015). Secondly, adipose tissue is strongly associated with inflammatory cells. In CAC patients, systemic inflammation is one of the major driving forces for adipose wasting. Released by tumor cells and activated immune cells, inflammatory cytokines, such as ZAG (Elattar et al., 2018) and TNF $\alpha$ (Patel and Patel, 2017), promote adipose wasting in CAC. Moreover, direct immune cell-adipocyte interaction may also drive cachexia (Baazim et al., 2019). Interestingly, in bonemarrow, adipocytes negatively regulate surrounding myeloid cells (Naveiras et al., 2009). However, in an adipose-wasting setting, such as anorexia nervosa, bone-marrow adipocytes do not undergo lipolysis but paradoxically expand (Bredella et al., 2009). These interesting findings need to be investigated in CAC. Thirdly, as previously mentioned, adipocyte-tumor cell communication includes adipocyte lipolysis, which stimulates tumor growth (Sauer et al., 1986), and tumor cell-derived cytokines or hormones that drive the browning process (Kir et al., 2014; Petruzzelli et al., 2014; Elattar et al., 2018).

Cancer-associated cachexia is a syndrome involving multiple organs and tissues. Between the adipocyte and various nonadipocytes, direct and indirect communication exists in the context of CAC. The molecular mechanisms of lipolysis and 
thermogenesis in three types of adipocytes, as well as the adipose tissue crosstalk, are summarized in Figure 1.

\section{Animal Models Used in CAC Research}

Appropriate animal models are crucial for understanding the mechanisms for clinical therapy. Over the years, various animal models have been proposed to mimic CAC. Due to the complexity of CAC, animal models can be characterized by loss of muscle, loss of adipose tissue, systemic inflammation, or anorexia. During the last decade, tumor-bearing rodent models have been upgraded. Genetically modified animal models have been developed for better mimicking the clinical situation. New animal species, such as zebrafish, are generated for CAC studies. Here, we review the commonly used animal model for CAC in Table 1, with detailed information on animal species, genetic modification, experimental period, weight loss, muscle loss, and, importantly, adipose tissue wasting.

Due to the heterogeneity of human cancers, none of the experimental models are suitable for the complete recapitulation of the clinical CAC features. Xenograft mouse models are easy to establish. However, fast tumor progression normally masks the CAC progression. Genetic models recapitulate the oncogenesis process and some genetic features in the clinic, while the non-stable occurrence rate limits further studies. In general, experimental mammal CAC models are useful for investigating adipose tissue-tumor communications, especially BAT-tumor communications. While the zebrafish or drosophila models may not perfectly reflect CAC features, their fast generating time and the convenience with which to produce the wild type or mutants make them attractive for drug screens. Notably, there is a lack of guidelines and consensus in CAC models, even in the most common models. Due to the non-standardized experimental conditions and CAC outcome measurements, the same model may behave differently. It increases the complexity of this field (Penna et al., 2016).

\section{Therapeutic Advances}

Medical interventions for cachexia are limited and urgently warranted. Nutritional supports involve caloric intake, marine n-3 fatty acids, amino acid, and micronutrients. The evidence of

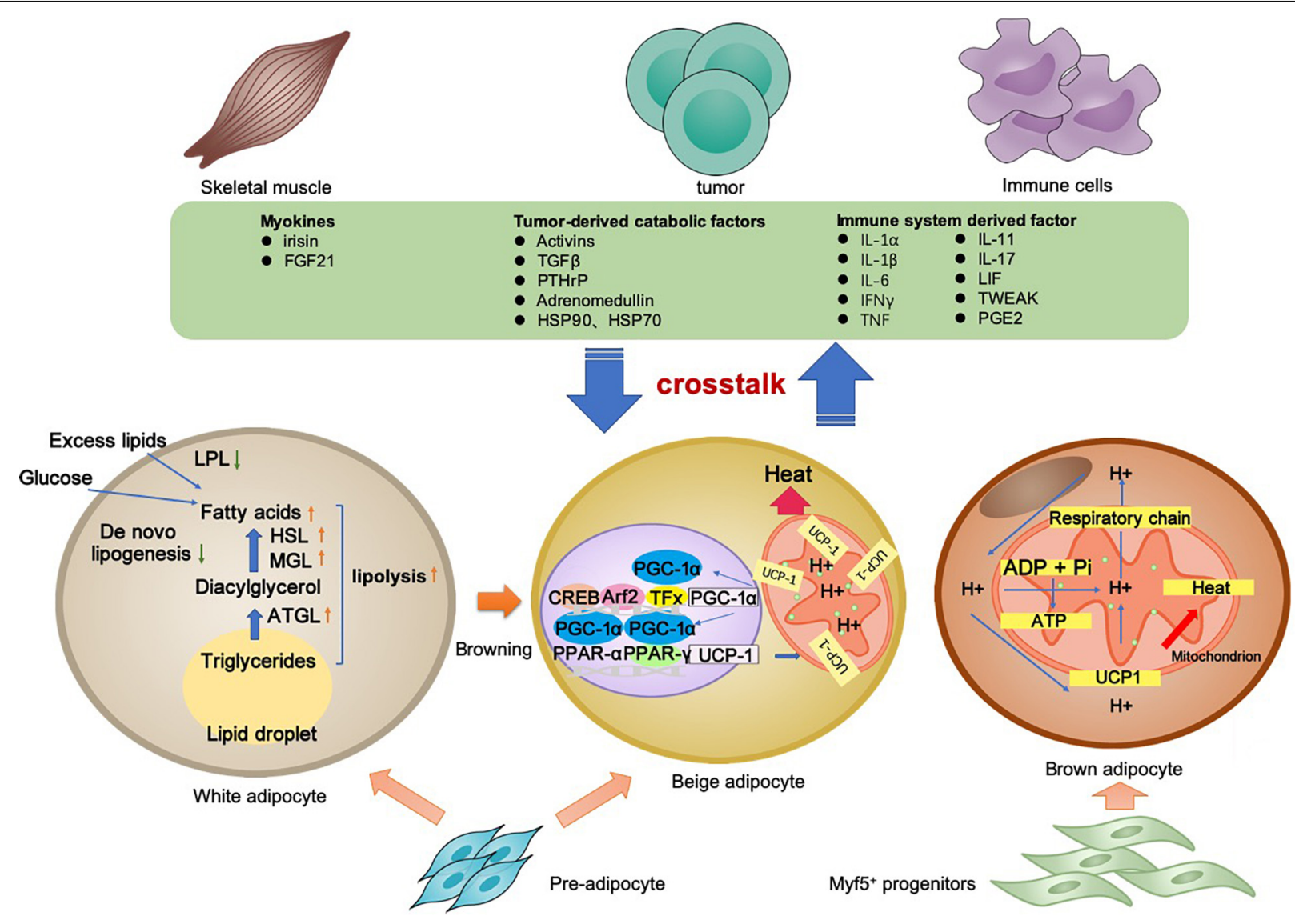

FIGURE 1 | Adipocyte-associated crosstalk influences metabolic homeostasis in CAC. In CAC, WAT undergoes increased lipolysis and reduced lipogenesis, which results in adipose tissue loss. In addition to lipolysis, white adipocyte browning and brown adipocyte activation stimulate UCP1 upregulation for thermogenesis and high energy expenditure. The adipocyte-myocyte, adipocyte-cancer cell, and adipocyte-inflammatory cell crosstalk influences metabolic homeostasis. Tumor-derived factors, adipokines, myokines, and other factors are all involved in the lipolysis and/or browning in adipose tissues. The adipose tissue wasting also has an effect on other organs through various pathway. Collectively, these changes result in a negative energy balance, which contributes to the development and progression of CAC. 
TABLE 1 | Animal models used in cancer-associated cachexia research.

\begin{tabular}{|c|c|c|c|c|c|c|}
\hline Animal model & Host & $\begin{array}{l}\text { Experimental } \\
\text { period (Day) }\end{array}$ & Weight loss (\%) & $\begin{array}{l}\text { Skeletal muscle } \\
\text { wasting }\end{array}$ & $\begin{array}{l}\text { Adipose tissue } \\
\text { wasting }\end{array}$ & References \\
\hline $\begin{array}{l}\text { Lewis lung carcinoma } \\
\text { (LLC) }\end{array}$ & C57BL/6 mice & 15 & 6.6 & $\begin{array}{l}\text { Yes (with reduced } \\
\text { cross-sectional } \\
\text { areas of muscle } \\
\text { fibers) }\end{array}$ & $\begin{array}{l}\text { Yes (with UCP1 } \\
\text { increased in BAT) }\end{array}$ & $\begin{array}{l}\text { Puppa et al., 2014; } \\
\text { Llovera et al., } 1998\end{array}$ \\
\hline $\begin{array}{l}\text { C26 colorectal } \\
\text { carcinoma }\end{array}$ & $\begin{array}{l}\text { BALB/c mice; } \\
\text { CD2F1 mice }\end{array}$ & 20 & 18 & $\begin{array}{l}\text { Yes }(20-30 \% \text { with } \\
\text { reduced } \\
\text { cross-sectional } \\
\text { areas of muscle } \\
\text { fibers) }\end{array}$ & $\begin{array}{l}\text { Yes }(70 \% \text { reduction } \\
\text { with UCP1 } \\
\text { increased in BAT) }\end{array}$ & $\begin{array}{l}\text { Bonetto et al., } \\
\text { 2016; Murphy } \\
\text { et al., } 2012\end{array}$ \\
\hline $\begin{array}{l}\text { Yoshida hepatoma } \\
(\mathrm{AH}-130)\end{array}$ & Wistar rats & 15 & 35 & $\begin{array}{l}\text { Yes (protein loss in } \\
\text { gastrocnemius and } \\
\text { heart muscle) }\end{array}$ & Yes & $\begin{array}{l}\text { Hoshino, 1963; } \\
\text { Tessitore et al., } \\
\text { 1993; Tschirner } \\
\text { et al., } 2012\end{array}$ \\
\hline $\begin{array}{l}\text { Walker } 256 \text { mammary } \\
\text { adenocarcinoma }\end{array}$ & $\begin{array}{l}\text { Sprague-Dawley } \\
\text { rats; Wistar rats }\end{array}$ & $14-21$ & 6 & $\begin{array}{l}\text { Yes (with } \\
\text { gastrocnemius } \\
\text { muscle reduced) }\end{array}$ & $\begin{array}{l}\text { Yes (with } \\
\text { decreased eWAT) }\end{array}$ & $\begin{array}{l}\text { Guaitani et al., } \\
1982\end{array}$ \\
\hline $\begin{array}{l}\text { Murine } \\
\text { adenocarcinoma } 16 \\
\text { (MAC16) }\end{array}$ & NMRI mice & $18-30$ & $20-33$ & $\begin{array}{l}\text { Yes ( } 20 \% \text { with } \\
\text { UCP-2 and -3 } \\
\text { increased in } \\
\text { skeletal muscle) }\end{array}$ & $\begin{array}{l}\text { Yes }(67 \% \text { reduction } \\
\text { with UCP1 } \\
\text { increased in BAT) }\end{array}$ & $\begin{array}{l}\text { Bibby et al., 1987; } \\
\text { Bing et al., } 2000\end{array}$ \\
\hline $\mathrm{Apc} c^{\min /+}$ & C57BL/6 mice & $84-140$ & $20-25$ & $\begin{array}{l}\text { Yes (with reduced } \\
\text { mitochondrial } \\
\text { content in } \\
\text { gastrocnemius } \\
\text { muscle) }\end{array}$ & $\begin{array}{l}\text { Yes (with } \\
\text { decreased eWAT) }\end{array}$ & $\begin{array}{l}\text { Baltgalvis et al., } \\
\text { 1985; Puppa et al., } \\
2011\end{array}$ \\
\hline $\begin{array}{l}\mathrm{Tsc}^{+/-} \mathrm{E} \mu-\mathrm{Myc} \\
\text { lymphoma }\end{array}$ & C57BL/6 mice & $9-20$ & $\sim 20$ & $\begin{array}{l}\text { Yes (significant loss } \\
\text { of muscle mass) }\end{array}$ & $\begin{array}{l}\text { Yes (complete loss } \\
\text { of adipose tissue) }\end{array}$ & Robert et al., 2012 \\
\hline $\begin{array}{l}\text { MKN45c185 and } \\
\text { 85As2 Stomach cancer }\end{array}$ & $\begin{array}{l}\text { F344/NJcl-rnu/rnu } \\
\text { rats }\end{array}$ & 28 & $4-8$ & Yes & Yes & $\begin{array}{l}\text { Takeda et al., 2008; } \\
\text { Fujitsuka et al., } \\
\text { 2011; Yanagihara } \\
\text { et al., 2013; } \\
\text { Terawaki et al., } \\
2014\end{array}$ \\
\hline $\begin{array}{l}\text { MDA-MB-231 breast } \\
\text { cancer bone metastasis }\end{array}$ & Nude mice & 20 & 12 & $\begin{array}{l}\text { Yes (with } \\
\text { gastrocnemius, } \\
\text { tibialis anterior, and } \\
\text { extensor digitorum } \\
\text { longus muscle } \\
\text { decreased) }\end{array}$ & / & Hain et al., 2019 \\
\hline $\begin{array}{l}\text { ASV-B hepatocellular } \\
\text { carcinoma }\end{array}$ & C57BL/6 mice & 119 & 34 & $\begin{array}{l}\text { Yes (decreased in } \\
\text { mass of } \\
\text { gastrocnemius, } \\
\text { tibialis anterior, and } \\
\text { extensor digitorum } \\
\text { longus muscle) }\end{array}$ & $\begin{array}{l}\text { Yes (with } \\
\text { decreased eWAT) }\end{array}$ & Erdem et al., 2019 \\
\hline $\begin{array}{l}\mathrm{S} 2-013, \mathrm{PANC} 1, \mathrm{PaO} 4 \\
\text { pancreatic cancer }\end{array}$ & nude mice & 10 & $6-15$ & $\begin{array}{l}\text { Yes (with reduced } \\
\text { cross-sectional } \\
\text { areas of muscle } \\
\text { fibers) }\end{array}$ & Yes & $\begin{array}{l}\text { Shukla et al., } 2014 \text {, } \\
\text { 2015; Winnard } \\
\text { et al., } 2016\end{array}$ \\
\hline $\begin{array}{l}\text { KRAS } 12 \mathrm{D} /+ \\
\text { P53 } \\
\text { (KPC) mouse }\end{array}$ & C57BL/6 mice & $5-14$ & / & $\begin{array}{l}\text { Yes }(4.5-7.7 \% \\
\text { reduction) }\end{array}$ & $\begin{array}{l}\text { Yes }(52.6-69 \% \\
\text { reduction. With } \\
\text { UCP1 decreased in } \\
\text { WAT and BAT) }\end{array}$ & $\begin{array}{l}\text { Michaelis et al., } \\
2017\end{array}$ \\
\hline $\begin{array}{l}\mathrm{Kras}^{+/ G 12 D} \\
\text { Ptf1a+/ER-Cre Pten }{ }^{f / f} \\
\text { (KPP) mouse }\end{array}$ & C57BL/6 mice & 107 & $\sim 25$ & $\begin{array}{l}\text { Yes (decreased } \\
\text { tibialis anterior, } \\
\text { quadriceps femoris, } \\
\text { and gastrocnemius } \\
\text { muscle masses) }\end{array}$ & $\begin{array}{l}\text { Yes (with eWAT and } \\
\text { iBAT decreased) }\end{array}$ & Talbert et al., 2019 \\
\hline $\begin{array}{l}\text { Kras }^{\mathrm{G} 12 V_{\text {-induced }}} \\
\text { hepatocellular } \\
\text { carcinoma }\end{array}$ & Zebrafish & 28 & 30 & $\begin{array}{l}\text { Yes (increased level } \\
\text { of fibrosis along } \\
\text { with the loss of } \\
\text { muscle fibers) }\end{array}$ & / & Yang et al., 2019 \\
\hline Scrib Ras ${ }^{V 12}$ tumor & Drosophila & 5 & / & $\begin{array}{l}\text { Yes (muscle ATP } \\
\text { levels reduced) }\end{array}$ & $\begin{array}{l}\text { Yes (fat body } \\
\text { marked reduction) }\end{array}$ & $\begin{array}{l}\text { Figueroa-Clarevega } \\
\text { and Bilder, } 2015\end{array}$ \\
\hline
\end{tabular}


this nutrition supports is limited. Apart from this, clinically, there has been a lack of a standard for nutrition support until now (Gullett et al., 2011).

Anti-CAC drug therapy has been continuously proposed over the last three decades. Appetite stimulants, such as megestrol acetate or tetrahydrocannabinol, promote food intake but show no effect on survival (Jatoi et al., 2002; Lesniak et al., 2008). Anabolic factors aiming to maintain body mass have been proposed for CAC. Hormones such as oxandrolone increase lean body mass but not fat body mass in CAC patients (Lesser et al., 2008). Ghrelin, a growth hormone stimulator secreted by the stomach, shows significant improvement in lean body mass (Garcia et al., 2007). A muscle-specific androgen receptor modulator improves lean body mass but failed in later larger trials (Dalton et al., 2011). Anti-inflammatory drugs, such as NSAIDs, improve weight gain (Lai et al., 2008). However, the $\mathrm{TNF} \alpha$ inhibitor does not show clinical significance in CAC patients (Jatoi et al., 2010). Recently, various targets, including muscle stem cells (Rinaldi and Perlingeiro, 2014), statins (Palus et al., 2013), mitochondria (van der Ende et al., 2018), and microbiota (Fukawa et al., 2016), have been proposed for novel therapeutic options. However, clinically, only a handful of drugs are approved for treating CAC patients. The majority of them are appetite stimulants. Notably, Anamorelin, a promising selective agonist of ghrelin, significantly increases lean body mass, but did not affect muscle strength or quality of life in a phase III trial (Temel et al., 2016), and it was thus rejected by the European Medicines Agency in 2017.

Targeting the adipose tissue for CAC therapy has been proposed but not yet proven in the clinic. New therapies that block adipose tissue lipolysis and/or thermogenesis can potentially be used to treat cachexia.

\section{CONCLUSION}

Cancer-associated cachexia is a chronic disease with multiple organs or tissues involved. Clinically, a novel therapy is warranted for not only achieving weight gain but also increasing the quality of life. Recent advances highlight the adipose tissue involvement in CAC. Among adipose tissues, WAT guides systemic energy production via the balance between

\section{REFERENCES}

Agustsson, T., Ryden, M., Hoffstedt, J., van Harmelen, V., Dicker, A., Laurencikiene, J., et al. (2007). Mechanism of increased lipolysis in cancer cachexia. Cancer Res. 67, 5531-5537. doi: 10.1158/0008-5472.CAN-064585

Argiles, J. M., Busquets, S., Stemmler, B., and Lopez-Soriano, F. J. (2014). Cancer cachexia: understanding the molecular basis. Nat. Rev. Cancer 14, 754-762. doi: $10.1038 / \mathrm{nrc} 3829$

Argiles, J. M., Lopez-Soriano, F. J., Toledo, M., Betancourt, A., Serpe, R., and Busquets, S. (2011). The cachexia score (CASCO): a new tool for staging cachectic cancer patients. J. Cachexia Sarcopenia Muscle 2, 87-93. doi: 10.1007/ s13539-011-0027-5

Argiles, J. M., Stemmler, B., Lopez-Soriano, F. J., and Busquets, S. (2018). Intertissue communication in cancer cachexia. Nat. Rev. Endocrinol. 15, 9-20. doi: 10.1038/s41574-018-0123-0 lipogenesis and lipolysis. BAT has recently been identified in adult humans with profound physiopathological functions. The browning process stimulates beige adipocyte differentiation and thermogenesis. These adipose tissues contribute to CAC differently. During CAC development, adipose tissues crosstalk with other cell types or organs and exhibit therapeutic potential. In this field, the key issues remain: (1) How are white/beige/brown adipocytes regulated in CAC pathological status? (2) What are the molecular details for adipocyte-nonadipocyte communications in CAC? (3) Are there better animal models for investigating adipose tissues in CAC? (4) What is the system-level landscape for adipose tissues in CAC? Altogether, the ultimate goal in this field will be to identify new targets in adipose tissues for treating CAC. The mechanistic studies need to be validated in clinical trials and translated into therapies for combating CAC.

\section{AUTHOR CONTRIBUTIONS}

$\mathrm{XS}$ and YY generated the ideas, reviewed publications, and wrote the manuscript. XF, XW, YL, KC, and YY participated in discussions.

\section{FUNDING}

XW was supported by the National Science Foundation of China (91539104), the Natural Science Foundation of Guangdong Province (2019A1515011421), and the Natural Science Foundation of Shenzhen University General Hospital (SUGH2018QD048). KC was supported by Startup Fund for Scientific Research, Fujian Medical University (2017XQ1186). YY was supported by the National Natural Science Foundation of China (81600839) and Shanghai Municipal Health Commission (20164Y0222).

\section{ACKNOWLEDGMENTS}

We thank Ms. Kaijing Gao for her artistic input and Dr. Sisi Xie for her comments on the manuscript.

Baazim, H., Schweiger, M., Moschinger, M., Xu, H., Scherer, T., Popa, A., et al. (2019). CD8(+) T cells induce cachexia during chronic viral infection. Nat. Immunol. 20, 701-710. doi: 10.1038/s41590-019-0397-y

Baltgalvis, K. A., Berger, F. G., Pena, M. M., Mark, Davis J, White, J. P., and Carson, J. A. (1985). Activity level, apoptosis, and development of cachexia in Apc(Min/+) mice. J. Appl. Physiol. 109, 1155-1161. doi: 10.1152/japplphysiol. 00442.2010

Bibby, M. C., Double, J. A., Ali, S. A., Fearon, K. C., Brennan, R. A., and Tisdale, M. J. (1987). Characterization of a transplantable adenocarcinoma of the mouse colon producing cachexia in recipient animals. J. Natl. Cancer Inst. 78, 539-546.

Bing, C., Bao, Y., Jenkins, J., Sanders, P., Manieri, M., Cinti, S., et al. (2004). Zincalpha2-glycoprotein, a lipid mobilizing factor, is expressed in adipocytes and is up-regulated in mice with cancer cachexia. Proc. Natl. Acad. Sci. U.S.A. 101, 2500-2505. doi: 10.1073/pnas.0308647100

Bing, C., Brown, M., King, P., Collins, P., Tisdale, M. J., and Williams, G. (2000). Increased gene expression of brown fat uncoupling protein (UCP)1 and skeletal 
muscle UCP2 and UCP3 in MAC16-induced cancer cachexia. Cancer Res. 60, 2405-2410.

Blum, D., Omlin, A., Baracos, V. E., Solheim, T. S., Tan, B. H., Stone, P., et al. (2011). Cancer cachexia: a systematic literature review of items and domains associated with involuntary weight loss in cancer. Crit. Rev. Oncol. Hematol. 80, 114-144. doi: 10.1016/j.critrevonc.2010.10.004

Bonetto, A., Rupert, J. E., Barreto, R., and Zimmers, T. A. (2016). The colon-26 carcinoma tumor-bearing mouse as a model for the study of cancer cachexia. Jove J. Vis. Exp. 117. doi: 10.3791/54893

Bostrom, P., Wu, J., Jedrychowski, M. P., Korde, A., Ye, L., Lo, J. C., et al. (2012). A PGC1-alpha-dependent myokine that drives brown-fat-like development of white fat and thermogenesis. Nature 481, 463-U72. doi: 10.1038/nature10777

Bredella, M. A., Fazeli, P. K., Miller, K. K., Misra, M., Torriani, M., Thomas, B. J., et al. (2009). Increased bone marrow fat in anorexia nervosa. J. Clin. Endocrinol. Metab. 94, 2129-2136. doi: 10.1210/jc.2008-2532

Brooks, S. L., Neville, A. M., Rothwell, N. J., Stock, M. J., and Wilson, S. (1981). Sympathetic activation of brown-adipose-tissue thermogenesis in cachexia. Biosci. Rep. 1, 509-517. doi: 10.1007/bf01121584

Cao, D. X., Wu, G. H., Yang, Z. A., Zhang, B., Jiang, Y., Han, Y. S., et al. (2010). Role of beta 1-adrenoceptor in increased lipolysis in cancer cachexia. Cancer Sci. 101, 1639-1645. doi: 10.1111/j.1349-7006.2010.01582.x

Dalton, J. T., Barnette, K. G., Bohl, C. E., Hancock, M. L., Rodriguez, D., Dodson, S. T., et al. (2011). The selective androgen receptor modulator GTx-024 (enobosarm) improves lean body mass and physical function in healthy elderly men and postmenopausal women: results of a double-blind, placebo-controlled phase II trial. J. Cachexia Sarcopenia Muscle 2, 153-161. doi: 10.1007/s13539011-0034-6

Das, S. K., Eder, S., Schauer, S., Diwoky, C., Temmel, H., Guertl, B., et al. (2011). Adipose triglyceride lipase contributes to cancer-associated cachexia. Science 333, 233-238. doi: 10.1126/science.1198973

Dutchak, P. A., Katafuchi, T., Bookout, A. L., Choi, J. H., Yu, R. T., Mangelsdorf, D. J., et al. (2012). Fibroblast growth factor-21 regulates PPAR gamma activity and the antidiabetic actions of thiazolidinediones. Cell 148, 556-567. doi: 10. 1016/j.cell.2011.11.062

Elattar, S., Dimri, M., and Satyanarayana, A. (2018). The tumor secretory factor ZAG promotes white adipose tissue browning and energy wasting. FASEB J. 32, 4727-4743. doi: 10.1096/fj.201701465RR

Erdem, M., Mockel, D., Jumpertz, S., John, C., Fragoulis, A., Rudolph, I., et al. (2019). Macrophages protect against loss of adipose tissue during cancer cachexia. J. Cachexia Sarcopenia Muscle 10, 1128-1142. doi: 10.1002/jcsm. 12450

Fearon, K., Strasser, F., Anker, S. D., Bosaeus, I., Bruera, E., Fainsinger, R. L., et al. (2011). Definition and classification of cancer cachexia: an international consensus. Lancet Oncol. 12, 489-495. doi: 10.1016/S1470-2045(10)70218-7

Figueroa-Clarevega, A., and Bilder, D. (2015). Malignant Drosophila tumors interrupt insulin signaling to induce cachexia-like wasting. Dev. Cell 33, 47-55. doi: 10.1016/j.devcel.2015.03.001

Fujitsuka, N., Asakawa, A., Uezono, Y., Minami, K., Yamaguchi, T., Niijima, A., et al. (2011). Potentiation of ghrelin signaling attenuates cancer anorexiacachexia and prolongs survival. Transl. Psychiatry 1:e23. doi: 10.1038/tp. 2011.25

Fukawa, T., Yan-Jiang, B. C., Min-Wen, J. C., Jun-Hao, E. T., Huang, D., Qian, C. N., et al. (2016). Excessive fatty acid oxidation induces muscle atrophy in cancer cachexia. Nat. Med. 22, 666-671. doi: 10.1038/nm.4093

Garcia, J., Boccia, R. V., Graham, C., Kumor, K., and Polvino, W. (2007). A phase II randomized, placebo-controlled, double-blind study of the efficacy and safety of RC-1291 (RC) for the treatment of cancer cachexia. J. Clin. Oncol. 25, 9133-9133.

Guaitani, A., Recchia, M., Carli, M., Rocchetti, M., Bartosek, I., and Garattini, S. (1982). Walker carcinoma 256: a model for studies on tumor-induced anorexia and cachexia. Oncology 39, 173-178. doi: 10.1159/000225631

Gullett, N. P., Mazurak, V. C., Hebbar, G., and Ziegler, T. R. (2011). Nutritional interventions for cancer-induced cachexia. Curr. Probl. Cancer 35, 58-90. doi: 10.1016/j.currproblcancer.2011.01.001

Hain, B. A., Xu, H., Wilcox, J. R., Mutua, D., and Waning, D. L. (2019). Chemotherapy-induced loss of bone and muscle mass in a mouse model of breast cancer bone metastases and cachexia. JCSM Rapid Commun. 2:e00075.
Holroyde, C. P., and Reichard, G. A. (1981). Carbohydrate metabolism in cancer cachexia. Cancer Treat. Rep. 65(Suppl. 5), 55-59.

Hoshino, M. (1963). Submicroscopic characteristics of four strains of Yoshida ascites hepatoma of rats: a comparative study. Cancer Res. 23, 209-216.

Hu, W. J., Ru, Z. Y., Xiao, W., Xiong, Z. Y., Wang, C., Yuan, C. F., et al. (2018). Adipose tissue browning in cancer-associated cachexia can be attenuated by inhibition of exosome generation. Biochem. Biophys. Res. 506, 122-129. doi: 10.1016/j.bbrc.2018.09.139

Iwamoto, H., Abe, M., Yang, Y., Cui, D., Seki, T., Nakamura, M., et al. (2018). Cancer Lipid Metabolism confers antiangiogenic drug resistance. Cell Metab. 28, 104-117.e5. doi: 10.1016/j.cmet.2018.05.005

Jatoi, A., Ritter, H. L., Dueck, A., Nguyen, P. L., Nikcevich, D. A., Luyun, R. F., et al. (2010). A placebo-controlled, double-blind trial of infliximab for cancerassociated weight loss in elderly and/or poor performance non-small cell lung cancer patients (N01C9). Lung Cancer 68, 234-239. doi: 10.1016/j.lungcan. 2009.06.020

Jatoi, A., Windschitl, H. E., Loprinzi, C. L., Sloan, J. A., Dakhil, S. R., Mailliard, J. A., et al. (2002). Dronabinol versus megestrol acetate versus combination therapy for cancer-associated anorexia: a north central cancer treatment group study. J. Clin. Oncol. 20, 567-573. doi: 10.1200/JCO.2002.20.2.567

Julienne, C. M., Dumas, J. F., Goupille, C., Pinault, M., Berri, C., Collin, A., et al. (2012). Cancer cachexia is associated with a decrease in skeletal muscle mitochondrial oxidative capacities without alteration of ATP production efficiency. J. Cachexia Sarcopeni. 3, 265-275. doi: 10.1007/s13539-012-0071-9

Kalra, P. R., and Tigas, S. (2002). Regulation of lipolysis: natriuretic peptides and the development of cachexia. Int. J. Cardiol. 85, 125-132. doi: 10.1016/s01675273(02)00241-3

Kir, S., White, J. P., Kleiner, S., Kazak, L., Cohen, P., Baracos, V. E., et al. (2014). Tumour-derived PTH-related protein triggers adipose tissue browning and cancer cachexia. Nature 513, 100-104. doi: 10.1038/nature13528

Kovsan, J., Ben-Romano, R., Souza, S. C., Greenberg, A. S., and Rudich, A. (2007). Regulation of adipocyte lipolysis by degradation of the perilipin protein: nelfinavir enhances lysosome-mediated perilipin proteolysis. J. Biol. Chem. 282, 21704-21711. doi: 10.1074/jbc.M702223200

Lai, V., George, J., Richey, L., Kim, H. J., Cannon, T., Shores, C., et al. (2008). Results of a pilot study of the effects of celecoxib on cancer cachexia in patients with cancer of the head, neck, and gastrointestinal tract. Head Neck 30, 67-74. doi: 10.1002/hed.20662

Lee, Y. H., Petkova, A. P., Konkar, A. A., and Granneman, J. G. (2015). Cellular origins of cold-induced brown adipocytes in adult mice. FASEB J. 29, 286-299. doi: 10.1096/fj.14-263038

Lepper, C., and Fan, C. M. (2010). Inducible lineage tracing of Pax7-descendant cells reveals embryonic origin of adult satellite cells. Genesis 48, 424-436. doi: 10.1002/dvg.20630

Lesniak, W., Bala, M., Jaeschke, R., and Krzakowski, M. (2008). Effects of megestrol acetate in patients with cancer anorexia-cachexia syndrome-a systematic review and meta-analysis. Pol. Arch. Med. Wewn. 118, 636-644.

Lesser, G. J., Case, D., Ottery, F., McQuellon, R., Choksi, J. K., Sanders, G., et al. (2008). A phase III randomized study comparing the effects of oxandrolone (Ox) and megestrol acetate (Meg) on lean body mass (LBM), weight (wt) and quality of life (QOL) in patients with solid tumors and weight loss receiving chemotherapy. J. Clin. Oncol. 26, 9513-9513. doi: 10.1200/jco.2008.26.15_ suppl.9513

Llovera, M., Carbo, N., Lopez-Soriano, J., Garcia-Martinez, C., Busquets, S., Alvarez, B., et al. (1998). Different cytokines modulate ubiquitin gene expression in rat skeletal muscle. Cancer Lett. 133, 83-87. doi: 10.1016/s03043835(98)00216-x

Long, J. Z., Svensson, K. J., Tsai, L., Zeng, X., Roh, H. C., Kong, X., et al. (2014). A smooth muscle-like origin for beige adipocytes. Cell Metab. 19, 810-820. doi: 10.1016/j.cmet.2014.03.025

Marinovic, M. P., Campeiro, J. D., Lima, S. C., Rocha, A. L., Nering, M. B., Oliveira, E. B., et al. (2018). Crotamine induces browning of adipose tissue and increases energy expenditure in mice. Sci. Rep. 8:5057. doi: 10.1038/s41598-018-22988- 1

McDonald, M. E., Li, C., Bian, H., Smith, B. D., Layne, M. D., and Farmer, S. R. (2015). Myocardin-related transcription factor A regulates conversion of progenitors to beige adipocytes. Cell 160, 105-118. doi: 10.1016/j.cell.2014. 12.005 
Michaelis, K. A., Zhu, X., Burfeind, K. G., Krasnow, S. M., Levasseur, P. R., Morgan, T. K., et al. (2017). Establishment and characterization of a novel murine model of pancreatic cancer cachexia. J. Cachexia Sarcopenia Muscle 8, 824-838. doi: 10.1002/jcsm. 12225

Murphy, K. T., Chee, A., Trieu, J., Naim, T., and Lynch, G. S. (2012). Importance of functional and metabolic impairments in the characterization of the C-26 murine model of cancer cachexia. Dis. Model. Mech. 5, 533-545. doi: 10.1242/ dmm.008839

Naveiras, O., Nardi, V., Wenzel, P. L., Hauschka, P. V., Fahey, F., and Daley, G. Q. (2009). Bone-marrow adipocytes as negative regulators of the haematopoietic microenvironment. Nature 460, 259-263. doi: 10.1038/nature08099

Nguyen, K. D., Qiu, Y., Cui, X., Goh, Y. P., Mwangi, J., David, T., et al. (2011). Alternatively activated macrophages produce catecholamines to sustain adaptive thermogenesis. Nature 480, 104-108. doi: 10.1038/nature10653

Notarnicola, M., Miccolis, A., Tutino, V., Lorusso, D., and Caruso, M. G. (2012). Low levels of lipogenic enzymes in peritumoral adipose tissue of colorectal cancer patients. Lipids 47, 59-63. doi: 10.1007/s11745-011-3630-5

Oliff, A., Defeo-Jones, D., Boyer, M., Martinez, D., Kiefer, D., Vuocolo, G., et al. (1987). Tumors secreting human TNF/cachectin induce cachexia in mice. Cell 50, 555-563. doi: 10.1016/0092-8674(87)90028-6

Palus, S., von Haehling, S., Flach, V. C., Tschirner, A., Doehner, W., Anker, S. D., et al. (2013). Simvastatin reduces wasting and improves cardiac function as well as outcome in experimental cancer cachexia. Int. J. Cardiol. 168, 3412-3418. doi: 10.1016/j.ijcard.2013.04.150

Patel, H. J., and Patel, B. M. (2017). TNF-alpha and cancer cachexia: molecular insights and clinical implications. Life Sci. 170, 56-63. doi: 10.1016/j.lfs.2016. 11.033

Pellegrinelli, V., Rouault, C., Rodriguez-Cuenca, S., Albert, V., Edom-Vovard, F., Vidal-Puig, A., et al. (2015). Human adipocytes induce inflammation and atrophy in muscle cells during obesity. Diabetes 64, 3121-3134. doi: 10.2337/ db14-0796

Penna, F., Busquets, S., and Argiles, J. M. (2016). Experimental cancer cachexia: evolving strategies for getting closer to the human scenario. Semin. Cell Dev. Biol. 54, 20-27. doi: 10.1016/j.semcdb.2015.09.002

Petruzzelli, M., Schweiger, M., Schreiber, R., Campos-Olivas, R., Tsoli, M., Allen, J., et al. (2014). A switch from white to brown fat increases energy expenditure in cancer-associated cachexia. Cell Metab. 20, 433-447. doi: 10.1016/j.cmet.2014. 06.011

Puigserver, P., Wu, Z. D., Park, C. W., Graves, R., Wright, M., and Spiegelman, B. M. (1998). A cold-inducible coactivator of nuclear receptors linked to adaptive thermogenesis. Cell 92, 829-839. doi: 10.1016/S0092-8674(00) 81410-5

Puppa, M. J., Gao, S., Narsale, A. A., and Carson, J. A. (2014). Skeletal muscle glycoprotein 130's role in Lewis lung carcinoma-induced cachexia. FASEB J. 28, 998-1009. doi: 10.1096/fj.13-240580

Puppa, M. J., White, J. P., Sato, S., Cairns, M., Baynes, J. W., and Carson, J. A. (2011). Gut barrier dysfunction in the $\mathrm{Apc}(\mathrm{Min} /+)$ mouse model of colon cancer cachexia. Biochim. Biophys. Acta 1812, 1601-1606. doi: 10.1016/j.bbadis. 2011.08.010

Rinaldi, F., and Perlingeiro, R. C. (2014). Stem cells for skeletal muscle regeneration: therapeutic potential and roadblocks. Transl. Res. 163, 409-417. doi: $10.1016 /$ j.trsl.2013.11.006

Robert, F., Mills, J. R., Agenor, A., Wang, D., DiMarco, S., Cencic, R., et al. (2012). Targeting protein synthesis in a Myc/mTOR-driven model of anorexia-cachexia syndrome delays its onset and prolongs survival. Cancer Res. 72, 747-756. doi: 10.1158/0008-5472.CAN-11-2739

Rosen, E. D., Hsu, C. H., Wang, X. Z., Sakai, S., Freeman, M. W., Gonzalez, F. J., et al. (2002). C/EBP alpha induces adipogenesis through PPAR gamma: a unified pathway. Gene Dev. 16, 22-26. doi: 10.1101/gad.948702

Rosen, E. D., and Spiegelman, B. M. (2006). Adipocytes as regulators of energy balance and glucose homeostasis. Nature 444, 847-853. doi: 10.1038/ nature 05483

Rosen, E. D., and Spiegelman, B. M. (2014). What We Talk About When We Talk About Fat. Cell 156, 20-44. doi: 10.1016/j.cell.2013.12.012

Rosenwald, M., Perdikari, A., Rulicke, T., and Wolfrum, C. (2013). Bi-directional interconversion of brite and white adipocytes. Nat. Cell Biol. 15, 659-667. doi: $10.1038 /$ ncb 2740
Ryden, M., Agustsson, T., Laurencikiene, J., Britton, T., Sjolin, E., Isaksson, B., et al. (2008). Lipolysis-not inflammation, cell death, or lipogenesis-is involved in adipose tissue loss in cancer cachexia. Cancer 113, 1695-1704. doi: 10.1002/ cncr.23802

Sauer, L. A., Nagel, W. O., Dauchy, R. T., Miceli, L. A., and Austin, J. E. (1986). Stimulation of tumor growth in adult rats in vivo during an acute fast. Cancer Res. 46, 3469-3475.

Schulz, T. J., Huang, P., Huang, T. L., Xue, R. D., McDougall, L. E., Townsend, K. L., et al. (2013). Brown-fat paucity due to impaired BMP signalling induces compensatory browning of white fat. Nature 495, 379-383. doi: 10.1038/ nature 11943

Seale, P., Bjork, B., Yang, W., Kajimura, S., Chin, S., Kuang, S., et al. (2008). PRDM16 controls a brown fat/skeletal muscle switch. Nature 454, 961-967. doi: $10.1038 /$ nature 07182

Seale, P., Kajimura, S., Yang, W., Chin, S., Rohas, L. M., Uldry, M., et al. (2007). Transcriptional control of brown fat determination by PRDM16. Cell Metab. 6, 38-54. doi: 10.1016/j.cmet.2007.06.001

Shellock, F. G., Riedinger, M. S., and Fishbein, M. C. (1986). Brown adipose tissue in cancer patients: possible cause of cancer-induced cachexia. J. Cancer Res. Clin. Oncol. 111, 82-85. doi: 10.1007/bf00402783

Shukla, S. K., Dasgupta, A., Mehla, K., Gunda, V., Vernucci, E., Souchek, J., et al. (2015). Silibinin-mediated metabolic reprogramming attenuates pancreatic cancer-induced cachexia and tumor growth. Oncotarget 6, 41146-41161. doi: 10.18632/oncotarget.5843

Shukla, S. K., Gebregiworgis, T., Purohit, V., Chaika, N. V., Gunda, V., Radhakrishnan, P., et al. (2014). Metabolic reprogramming induced by ketone bodies diminishes pancreatic cancer cachexia. Cancer Metab. 2:18. doi: 10.1186/ 2049-3002-2-18

Stephens, N. A., Skipworth, R. J., Macdonald, A. J., Greig, C. A., Ross, J. A., and Fearon, K. C. (2011). Intramyocellular lipid droplets increase with progression of cachexia in cancer patients. J. Cachexia Sarcopenia Muscle 2, 111-117. doi: 10.1007/s13539-011-0030-x

Stewart, G. D., Skipworth, R. J. E., and Fearon, K. C. H. (2006). Cancer cachexia and fatigue. Clin. Med. 6, 140-143. doi: 10.7861/clinmedicine.6-2-140

Strassmann, G., Fong, M., Kenney, J. S., and Jacob, C. O. (1992). Evidence for the involvement of interleukin 6 in experimental cancer cachexia. J. Clin. Invest. 89, 1681-1684. doi: 10.1172/JCI115767

Takeda, H., Sadakane, C., Hattori, T., Katsurada, T., Ohkawara, T., Nagai, K., et al. (2008). Rikkunshito, an herbal medicine, suppresses cisplatin-induced anorexia in rats via 5-HT2 receptor antagonism. Gastroenterology 134, 2004-2013. doi: 10.1053/j.gastro.2008.02.078

Talbert, E. E., Cuitino, M. C., Ladner, K. J., Rajasekerea, P. V., Siebert, M., Shakya, R., et al. (2019). Modeling human cancer-induced Cachexia. Cell Rep. 161:e4. doi: 10.1016/j.celrep.2019.07.016

Temel, J. S., Abernethy, A. P., Currow, D. C., Friend, J., Duus, E. M., Yan, Y., et al. (2016). Anamorelin in patients with non-small-cell lung cancer and cachexia (ROMANA 1 and ROMANA 2): results from two randomised, double-blind, phase 3 trials. Lancet Oncol. 17, 519-531. doi: 10.1016/S1470-2045(15)00558-6

Terawaki, K., Sawada, Y., Kashiwase, Y., Hashimoto, H., Yoshimura, M., Suzuki, M., et al. (2014). New cancer cachexia rat model generated by implantation of a peritoneal dissemination-derived human stomach cancer cell line. Am. J. Physiol. Endocrinol. Metab. 306, E373-E387. doi: 10.1152/ajpendo.00116.2013

Tessitore, L., Costelli, P., Bonetti, G., and Baccino, F. M. (1993). Cancer cachexia, malnutrition, and tissue protein turnover in experimental animals. Arch. Biochem. Biophys. 306, 52-58. doi: 10.1006/abbi.1993.1479

Tisdale, M. J. (2002). Cachexia in cancer patients. Nat. Rev. Cancer 2, 862-871. doi: $10.1038 / \operatorname{nrc} 927$

Trew, J. A., and Begg, R. W. (1959). In vitro incorporation of acetate-1-C14 into adipose tissue from normal and tumor-bearing rats. Cancer Res. 19, 1014-1019.

Tschirner, A., von Haehling, S., Palus, S., Doehner, W., Anker, S. D., and Springer, J. (2012). Ursodeoxycholic acid treatment in a rat model of cancer cachexia. J. Cachexia Sarcopenia Muscle 3, 31-36. doi: 10.1007/s13539-011-0044-4

Tseng, Y. H., Kokkotou, E., Schulz, T. J., Huang, T. L., Winnay, J. N., Taniguchi, C. M., et al. (2008). New role of bone morphogenetic protein 7 in brown adipogenesis and energy expenditure. Nature 454, 1000-1004. doi: 10.1038/ nature 07221 
van der Ende, M., Grefte, S., Plas, R., Meijerink, J., Witkamp, R. F., Keijer, J., et al. (2018). Mitochondrial dynamics in cancer-induced cachexia. Biochim. Biophys. Acta Rev. Cancer 1870, 137-150. doi: 10.1016/j.bbcan.2018.07.008

van Herpen, N. A., and Schrauwen-Hinderling, V. B. (2008). Lipid accumulation in non-adipose tissue and lipotoxicity. Physiol. Behav. 94, 231-241. doi: 10.1016/j. physbeh.2007.11.049

Vegiopoulos, A., Muller-Decker, K., Strzoda, D., Schmitt, I., Chichelnitskiy, E., Ostertag, A., et al. (2010). Cyclooxygenase-2 controls energy homeostasis in mice by de novo recruitment of brown adipocytes. Science 328, 1158-1161. doi: $10.1126 /$ science. 1186034

Veniant, M. M., Sivits, G., Helmering, J., Komorowski, R., Lee, J., Fan, W., et al. (2015). Pharmacologic effects of FGF21 are independent of the browning of white adipose tissue. Cell Metab. 21, 731-738. doi: 10.1016/j.cmet.2015.04.019

Walden, T. B., Hansen, I. R., Timmons, J. A., Cannon, B., and Nedergaard, J. (2012). Recruited vs. nonrecruited molecular signatures of brown, brite, and white adipose tissues. Am. J. Physiol. Endoc. M 302, E19-E31. doi: 10.1152/ ajpendo.00249.2011

Wang, B., Zhang, F., Zhang, H., Wang, Z., Ma, Y. N., Zhu, M. J., et al. (2017). Alcohol intake aggravates adipose browning and muscle atrophy in cancerassociated cachexia. Oncotarget 8, 100411-100420. doi: 10.18632/oncotarget. 22243

Wang, Q. A., Tao, C., Gupta, R. K., and Scherer, P. E. (2013). Tracking adipogenesis during white adipose tissue development, expansion and regeneration. Nat. Med. 19, 1338-1344. doi: 10.1038/nm.3324

Wang, W. S., Kissig, M., Rajakumari, S., Huang, L., Lim, H. W., Won, K. J., et al. (2014). Ebf2 is a selective marker of brown and beige adipogenic precursor cells. Proc. Natl. Acad. Sci. U.S.A. 111, 14466-14471. doi: 10.1073/pnas.141268 5111
Winnard, P. T. Jr., Bharti, S. K., Penet, M. F., Marik, R., Mironchik, Y., Wildes, F., et al. (2016). Detection of pancreatic cancer-induced cachexia using a fluorescent myoblast reporter system and analysis of metabolite abundance. Cancer Res. 76, 1441-1450. doi: 10.1158/0008-5472.CAN-15-1740

Wu, J., Bostrom, P., Sparks, L. M., Ye, L., Choi, J. H., Giang, A. H., et al. (2012). Beige adipocytes are a distinct type of thermogenic fat cell in mouse and human. Cell 150, 366-376. doi: 10.1016/j.cell.2012.05.016

Yanagihara, K., Takigahira, M., Mihara, K., Kubo, T., Morimoto, C., Morita, Y., et al. (2013). Inhibitory effects of isoflavones on tumor growth and cachexia in newly established cachectic mouse models carrying human stomach cancers. Nutr. Cancer 65, 578-589. doi: 10.1080/01635581.2013.776089

Yang, Q., Yan, C., Wang, X., and Gong, Z. (2019). Leptin induces muscle wasting in a zebrafish kras-driven hepatocellular carcinoma (HCC) model. Dis. Model. Mech. 12:dmm038240. doi: 10.1242/dmm.038240

Yang, X., Sui, W., Zhang, M., Dong, M., Lim, S., Seki, T., et al. (2017). Switching harmful visceral fat to beneficial energy combustion improves metabolic dysfunctions. JCI Insight. 2:e89044. doi: 10.1172/jci.insight.89044

Conflict of Interest: The authors declare that the research was conducted in the absence of any commercial or financial relationships that could be construed as a potential conflict of interest.

Copyright (c) 2020 Sun, Feng, Wu, Lu, Chen and Ye. This is an open-access article distributed under the terms of the Creative Commons Attribution License (CC BY). The use, distribution or reproduction in other forums is permitted, provided the original author(s) and the copyright owner(s) are credited and that the original publication in this journal is cited, in accordance with accepted academic practice. No use, distribution or reproduction is permitted which does not comply with these terms. 